\title{
Humanitarian and Conflict Oriented Early Warning: A Historical Background Sketch
}

\author{
Howard Adelman
}

\begin{abstract}
This article provides a brief and informative overview of the overall development of early warning over past years. It also includes references to the author's own involvement in the field as Director of the Centre for Refugee Studies and, later, Director of the Prevention/Early Warning Unit.

\section{Précis}

Cet article fournit un survol succinct et factuel du développement général du phénomène de l'alerte préventive dans les dernières années. On y retrouve notamment des informations sur l'implication personnelle de l'auteur dans ce domaine en sa qualité de directeur $d u$ Centre d'Études sur les Réfugiés et, par la suite, de l'Unité Prévention/Alerte Préventive.
\end{abstract}

There are two historical sources for the use of early warning as a concept. One is to be found in the intelligence community. Early warning referred to a party A possessing advance notification of an immanent hostile act by an enemy B enabling A to undertake preventive action which could deter or even compel B to cancel the planned action. A second source is to be found in reference to natural humanitarian disasters, initially with respect to weather storms or earthquakes, but then applied to draught conditions in order to anticipate famines. Thus, the Food and Agricultural Organization (FAO) developed the first early warn-

Howard Adelman is a Professor of Philosophy at York University, Toronto. He was the founder and Director of the Centre for Refugee Studies until 1993, and most recently headed its Early Warning/Prevention Unit.

This article is scheduled for publication in Early Warning and Conflict Prevention, edited by Klaas van Walraven (Hague: Kluwer Law International). ing system that was not self-defensive. It was designed to enable the FAO to stockpile and locate food supplies to prevent famine.

The first type of early warning system was designed to enable action to be taken to deter an enemy's threat or mitigate its effects. The second was also concerned with taking action, but to prevent or mitigate suffering of others.

In the UN system, early warning was initially associated with the first type and traditional intelligence gathering to detect, deter, prevent, or counter hostile acts against UN peacekeepers in the Congo. ${ }^{1}$ The roots of its contemporary conception, however, are to be found in the humanitarian area. Intent on enabling the UN to prepare for and perhaps even mitigate the causes of forced migration, a 1981 study by Prince Sadruddin for the UN Commission on Human Rights set forth a number of push and pull factors which contributed to forced migration. Prince Sadruddin recommended the creation of an early warning system within the UN to study and track these push and pull factors. This emphasis was reinforced when the Group of Government Experts to Avert New Refugee Flows formally requested the UN Secretary-General to establish an office to gather more complex information on refugee flows, and to report on that information in a timely fashion.

The UN system initially attempted to structure itself on the nation-state model by appending an intelligence apparatus to the executive office. Perez de Cuellar initiated ORCI, the Organization for Research and the Collection of Information in 1987 (Ramcharan 1991). The Secretary-General also envisioned that ORCI would serve the security as well as humanitarian mandate of the UN. In a perspective paper submitted to the General Assembly in the same year in which he established ORCI (A/42/512), he stated:

The United Nations must ... give very high priority in the 1990 s to monitoring potential causes of conflict and to communicating warning signs to those in a position to alleviate the situation. First responsibility should lie with the security Council and with the Secretary-General who will need to have the means to mount a global watch. Given the strong economic and social factors in regional violence, economic and social developments will have to be followed and assessed in terms of their relevance to international security [my italics]. ${ }^{2}$

The intelligence related to security differed from the intelligence capacity developed by the UN peacekeepers in the Congo crisis. The new security intelligence was not related to deterring, deflecting, or countering hostile actions directed at military troops, but rather to assist in preventive diplomacy. The latter use of security intelligence is distinct from, but related to, early warning geared to mitigating suffering resulting from socially and politically produced humanitarian disasters such as in alleviating the conditions which produce refugees.

It was in the latter capacity that $I$, as Director for the Centre for Refugee Studies at York University, became involved with ORCI as an academic research partner in the initial attempt to develop a Humanitarian Early Warning System. HEW had two focithe anticipation of refugee flows so that steps could be taken in advance to ensure health, water and food supplies as well as shelter were in place to mitigate the suffering of the refugees, and the anticipation of refugee flows so that preventive action could be taken to alleviate the causes stimulating the flow.

The costly resources needed to comprehensively gather, let alone assess, 
analyze and disseminate the information, were just not available. The chief officers of a very small staff did not even have the funds available to travel to meetings to discuss early warning in developing a partnership with research units based at universities. In the end, Boutros Boutros-Ghali abolished ORCI.

Since that time, particularly in the aftermath of the Rwanda fiasco, within the UN system, both the political (DPA and DPKO) and the humanitarian arms of the UN involved in global issues (both DHA and the UNHCR) have recognized the need for an international intelligence analysis capability. The UN in June of 1995 developed the Policy Analysis Team in the Department of Political Affairs (DPA) to "strengthen DPA's early warning and analytical capacity" (Ramcharan 1996, 3) to make policy recommendations. The Department of Humanitarian Affairs (DHA) has developed its Humanitarian Early Warning System (HEWS) (rooted in a complex indicator model) as well as its IRIN information sharing system on the Great Lakes region of Africa. The Department of Peacekeeping Operations (DPKO) has developed an Oversight Group to ensure the exchange of information and analysis between departments. These three branches meet at least weekly under the auspices of the SecretaryGeneral as an Interdepartmental Task Force to compare notes, determine priorities, and devise strategies. Left out of this loop, but integral to early warning, is the monitoring work of the United Nations Commission for Human Rights. ${ }^{3}$ In Geneva, DHA has also developed RefugeeNet as a complementary humanitarian input into the development of an early warning capacity.

In addition to the UN initiatives, projects underway in this field are located among three other groupsNGOs, academia, and states. The NGO sector-such as the Carnegie Commission, the Council on Foreign Relations in New York, International Alert in London-have initiated different models of early warning geared to dif- ferent forms of preventive diplomacy and different organizational models. A number of academics have attempted to develop theoretical models based on indicator systems and/or a large number of case studies. Finally, individual states on their own have taken up the issue of early warning-for example, in the CIA funding of the Minority-at-Risk project.

NGOs, with the cooperation and involvement of some international agencies such as the UNHCR, have attempted to develop a network model which depends on voluntary cooperation of a number of individuals and organizations. A key component is the sharing of information. Amnesty International is perhaps the most famous organization in the field of individual human rights abuses which utilizes a variation of this model. The various "Watch" organizations provide other examples. Academics and research centres (PIOOM in Holland, Ted Gurr's University of Maryland team, Hayward Alker, the Harvard group, have all attempted to develop theoretical models based on indicators and/or on comparative case studies, ${ }^{4}$ but have not had the resources to test the competing models and settle on one or two for development. ${ }^{5}$ Though preliminary attempts have been made to coordinate that research, mostly under the initiative of Ted Gurr, the development of a systematic network to deal with the theoretical arm can best be described as being at a primitive stage of development, even if the models themselves are much more advanced. The development of these theoretical models based on long term case study analysis seems esoteric compared with the urgency of the various crises in the field and the suspicion that such long term case study analyses can have little impact on a crisis which seems to be suddenly triggered by the crash of a plane carrying the President of a country (Rwanda) and the need to respond immediately to a conflict which appears to emerge like a volcano without warning.

The fourth structural component of an early warning system are states.
Though no state alone, except perhaps for the United States, has the capacity to develop and operate an early warning system to cover all potential complex emergencies on its own, states are reluctant to develop early warning systems as part of a consortium ${ }^{6}$ lest the results of such early warnings entail that they become involved in humanitarian actions which are not compatible or even run contrary to their self interests. Why have early warnings if you might not want to heed them? Yet only states have the basic capacity to manage such conflicts. And states, willy nilly, become involved, however reluctantly, in the humanitarian dilemmas of most complex emergencies.

However, very recent efforts have been taken to develop a consortium of all four groups to combine efforts to develop synergies, since none of the individual organizations or the smaller internationally-minded states on their own have the resources or capacity to monitor the myriad of complex emergencies around the globe. An NGO UK-based initiative, facilitated by International Alert, has formed a Working Group on Early Warning and Conflict Prevention to develop a network-based early warning and conflict prevention capacity. A consortium of agencies, academic research units, NGOs, and hopefully, internationallyminded states has combined efforts to develop a true international operating network involving all these groups in a single early warning system. The organization that resulted is called FEWER, the Forum for Early Warning and Emergency Response, founded in September of $19966^{7}$

The basic conception of early warning is based on a central system of indicators to provide guidance for independent specialized networks focused on crisis areas to gather and analyze data and develop response scenarios in a continuing system of monitoring. The linkage with emergency response has yet to be worked out.

With the development of a formal international consortium in this area, hopefully more attention can be 
shifted from structural problems to the issue of making such a system effective.

\section{Notes}

1. Cf. A. Walter Dorn and David J. H. Bell, "Intelligence and Peacekeeping: The UN Operation in the Congo, 1960-64," International Peacekeeping 1, no. 2 (Spring 1995): 11-33.

2. This quote was brought to my attention by B. G. Ramcharan at the Clingendael conference. Cf. B. G. Ramcharan, The International Law and Practice of EarlyWarning and Preventive Diplomacy, 1991, Chapter IV (Dordrecht, Boston: Martinus Nijhoff Publishers).

3. In his initial address to the Commission on Human Rights in 1994, the High Commissioner for Human Rights stated: "1 shall look into the viability of an 'early warning' mechanism that would enable us to take action in a timely manner to protect human action in a timely manner to protect human
rights." In his first report to the UN General rights." In his first report to the UN General
Assembly, he stated that, "It will be Assembly, he stated that, "It will be important in the future [my italics] to have which various elements of the United Nations human rights program could playa role in preventing the outbreak of serious violations of human rights." (A/49/36, para. 66) Cf. Ramcharan 1996 for a more para. 66) Cf. Ramcharan 1996 for a more
expansive discussion of these expansive
developments.

developments.
The following list of some early warning modellers attempts to summarize the approach of each of them:

i) Dr. John Davies, Center for Internaional Development and Conflict tional Development and Managentand, System), a near-real time data analysis System), a near-real time data analysis of actions

ii) Dr. Helen Fein, Executive Director of the Institute for the Study for Genocide at Harvard University in Cambridge, in her studies on genocide depicts genocide as a reactive or retibutive and massacre as instruments of policy in the absence of either internal social controls and external interventions; she has already tentatively applied her model to the Rwandan situation in an article in Refuge 14, no. 5, October 1994;

iii) Barbara Harff, Department of Political Science at the U.S. Naval Academy at Annapolis, and Ted Gurr, leading scholar and researcher in Early Warning research, have worked on developing a model of Early Warning applied to Intercommunal Conflict, taking into consideration the international background conditions as well as the internal ethic and political fragmentation and the absence of offsetting international and domestic countervailing

) Alex Schmidt and Bero Jongman of PIOOM (Programma Interdisciplinai Onderzoek naar Oorzaken va Mensenrechtenschendingen, in English: Interdisciplinary Research Program on Root Causes of Human Rights Violation) at the Center for the Study Violations) at the Center for the Study Uivivecity, has undertaken to Monitor University, has undertaken to Monitor Early Warning of Humanitarian Crise through data on cuI tural, social, economic and political conditions correlated with Human Rights Violations and has proposed developing a model-driven forecast system for assessing the risk of politicast system for assessing the risk of politica system for assessing the risk of political a broa data-gathering effort based on actual monitoring, combined with a statistical model and an expert-based coassessment;

v) the late Frank Sherman (along with Gavan Duffy and Stuart Thorson) at Syracuse University, worked with SHERFACS, a data set summarizing the conflict trajectories and managethe conflict trajectories and management efforts of over 1400 international
disputes and twice as many intrastate disputes and twice as many intrastate
disputes since 1945; Alex Schmid has disputes since 1945; Alex Schmid has
been the only one to run a test of two models;

vi) Professor David Singer of the Department of Political Science, University of Michigan works on Early Warning Signals for Culturally Distinct Groups in Danger;

vii) Rodney Tomlinson, Department of Political Science, U.S. Naval Academy, works with WEISS (Worl Event/Interaction Survey), a feedback survey model to ascertain the willingness of the respective parties to cooperate or engage in conflict;

viii) Jonathan Wilkenfeld, Department of Government and Politics at the
University of Maryland, and Michael University of Maryland, and Michae
Breecher of the Political Science Breecher of the Political Science Department at McGill University in Montreal, have applied their Model of Crisis, Conflict and Instability to the Ethnopolitical Dimensions of international crises.

5. Alex Schmid, "Early Detection of Emerging Political and Humanitarian Crises: An Early Warning Model for Assessing
Country Proneness to Conflict Escalation, PlOOM, p. 3.

6. There have been some efforts, however. The rather open Burundi Policy Forum and the wore insitum were instituted to connect intelligence from both states, acadennics and NGOs specializing in human rights monitoring, refugee advocacy, conflict resolution, and emergency relief to share information and devise appropriate responses from the extreme of deploying standby forces to more modest efforts geared to impeding arms flows, freezing extremist leaders' foreign bank accounts or their abilities to

7. The initial founding members included UNDHA, UNHCR, PIOOM, Centre for Preventive Action-council on Foreign Relations, the Prevention/Early Warning Unit of the Centre for Refugee Studies and the Centre for International and Security Studies at York University. The interim and temporary secretariat was housed at York. e founding members, scheduled to attend the second meeting in January of 1997 are CSS-Ethnobarometer, the Centre for European Studies (CEPS), a representative of the European Parliament, the Swiss Peace Foundation, the Institute of Ethnology and Anthropology-Russian Academy of Science, as well as representatives from Canada, Switzerland, and sentatives from possibly some of the Scandinavian countries. Three pilot area studies have been initiated. For example, the Early Warning/Prevention Unit at York University initiated a WARN (Western Africa Research Network) primarily focused on Nigeria.

\section{References}

Ramcharan, B. G. 1991. The International Law and Practice of Early-Warning and Preventive Diplomacy: The Emerging Global Watch. Dordrecht, Boston: Martinus Nijhoff Publishers.

- . 1996 (November). Unpublished presen tation. Clingendael, The Netherlands. CI

\section{Refuge}

Canada's Periodical on Refugees

is published six times a year by the

Centre for Refugee Studies,

York University, Toronto.

Email: refuge@yorku.ca http://www.yorku.ca/research/crs

Refuge, Vol. 16, No.1 (May 1997) 